\title{
Geographical approach of Industry 4.0 based on information and communication technologies at Hungarian enterprises in connection with industrial space
}

\author{
Éva KISS ${ }^{1}$ and ERzsÉBET NEDELKA ${ }^{2}$
}

\begin{abstract}
In the short history of Hungarian industry there were relevant changes several times, which had a great impact not only on industrial production and employment, but also on the spatial pattern of industry. After the regime change and latest economic crisis Industry 4.0 or/and the fourth industrial revolution mean(s) newer challenge. Due to information and communication technologies (ICT), which can be considered the basis of Industry 4.0 radical changes can be expected in all fields of life and numerous questions will emerge. The primary aim of this paper is to reveal the geography of older and newer information and communication technologies and their relationship with the spatial pattern of Hungarian industry. The main question is whether the digital divide follows the industrial divide in the Hungarian economic space or not. According to the analysis based on different ICT and industrial indicators, there is no close correlation between the digital and industrial spaces. The geography of Industry 4.0 is characterised by a sharp North-South division.
\end{abstract}

Keywords: Industry 4.0, fourth industrial revolution, ICT, industry, enterprise, spatial pattern, Hungary

Received November 2019, Accepted March 2020.

\section{Introduction}

In recent years Industry 4.0 has been the biggest challenge for the Hungarian economy as well. The concept was first used in Germany in 2011 (known as Industrie 4.0 at that time) for a combination of measures to strategically develop the industry there (Hermann, M. et al. 2015; BARTODZIEJ, C.J. 2017). In the international literature, however, it is known as Industry 4.0, but also referred to as Advanced Manufacturing Technology, Smart Factory or Internet of Things (Fonseca, L.M. 2018). Industry 4.0 essentially means new technologies that are based on digitalisation, automation and robotisation, and which are revolutionising industrial production. However, the impact of Industry 4.0 goes far beyond industry and will transform the economy and society as a whole (Kovécs, O.
2017). Today we are still at the beginning of this fundamental transformation from Industry 3.0, characterised by human-operated machines, towards production by automatic machines communicating with each other and with humans too (Devezas, T. et al. 2017).

There is no doubt that digital transformation, and these revolutionary changes will occur in different ways in both space and time (Rüssmann, M. et al. 2015). The transformation of countries and regions depends largely on their starting position and different capabilities (ŠLANDER, S. and Wostner, P. 2019). Among the initial conditions the focus in this study is on the geographical assessment of the infrastructure and use of the information and communication technologies underlying the spreading and unfoldment of Industry 4.0. After all, these (such as computer or internet access) are very im-

\footnotetext{
${ }^{1}$ Geographical Institute, Research Centre for Astronomy and Earth Sciences, Budapest, Hungary; University of Sopron, Alexandre Lamfalussy Faculty of Economics, H-9400 Sopron, Erzsébet u. 9. Hungary. E-mail: kiss.eva@csfk.mta.hu

${ }^{2}$ University of Sopron, Alexandre Lamfalussy Faculty of Economics, H-9400 Sopron, Erzsébet u. 9. Hungary.
} 
portant to the widespread application of new technologies and, thus, to the realisation of the fourth industrial revolution. Therefore, it does matter what characterises the provision of ICT to companies and their application. Their geographical examination, which has so far been little in the literature, provides indicative information to some extent, on the one hand, on the spatial differences in the use of ICT in Hungarian companies, and on the other hand, on how advanced they are in Industry 4.0. It can be assumed that the ICT indicators of enterprises are more favourable in regions in Hungary with more advanced industry, the verification of which is also one of the tasks of this analysis.

The present study consists of five main parts. Following the introduction, the concept of Industry 4.0 and fourth industrial revolution is discussed, and then the major conditions and characteristics of ICT at enterprises based on special literature are evaluated with particular regard to the geographical aspect. After the chapter on the methods, the spatial disparities of the older and more recent application of ICT by Hungarian companies are explored in the third part. Correlations between the info-communication maturity and the spatial structure of the industry are analysed in the fourth part before the conclusions.

\section{Theoretical background}

\section{Terminology and main research directions}

There have been three industrial revolutions over the last two hundred years, each of which had its own specifics, driving forces and major innovations. These appeared and spread differentiated in space and led to huge changes not only in industry, but also in the economy and society (MoKyr, J. 1985; Jensen, M.C. 1993; Авоnyi, F. and Miszlivetz, F. 2016).

The fourth industrial revolution or Industry 4.0, driven by nine fundamental technologies (Big Data, Autonomous robots, Simulation,
Horizontal and vertical integration, Internet of Things, Cybersecurity, Cloud service, Additive manufacturing, Augmented reality) began to unfold in the early $21^{\text {st }}$ century, however, the use of the word only spread rapidly in recent years. While the third industrial revolution (Industry 3.0), also known as the revolution of the computer or digital revolution (Sсншав, K. 2016), focused on the automation of individual machines and processes, the fourth industrial revolution (or Industry 4.0) focuses on the digitisation and automation of the entire process of production. Machines and production are organised into smart networks, integrating entire production chains, while deepening vertical and horizontal integration. Since it is highly likely that the current digital transformation will also result in radical changes in all aspects of life, many of which are not yet visible today, it can be considered rather revolution, by all means in the long-term, than evolution (Geissbauer, R. et al. 2016; Demeter, K. et al. 2019). However, some scientists supporting the latter consider the fourth industrial revolution being essentially the result of the further development of the third one, in other words, its completion (Holodny, E. 2017).

The fact that the terms Industry 4.0 and fourth industrial revolution are not fully cleared today can be explained partly by the above (Hermann, M. et al. 2015; Fonseca, L.M. 2018). It has not been decided either whether the two concepts have the same or different meanings. TновеN, K.D. et al. (2017) used them as synonyms because they believe these concepts have the potential to disrupt the entire conventional approach to manufacturing. In contrast, others think that in a closer sense Industry 4.0 refers to changes in the industry that cause significant transformation in the organisation and method of production, management, technology, etc. (NAGY, J. 2019). In short, Industry 4.0 means "the trend towards a digital revolution in manufacturing..." (SAntos, C. et al. 2017, 972) or „....a collective term for technologies and concepts of value chain organisation" (Hermann, M. et al. 2015, 11). According to 
BRETTEL, M. et al. $(2014,43)$, „, ... Industry 4.0 is a popular term to describe the imminent changes of the industry landscape, particularly in the production and manufacturing industry of the developed world." At the same time, the concept of the fourth industrial revolution can be interpreted more broadly because it represents changes in the economy and society as a whole, most of which are not yet known. In this study, the two concepts are used as Industry 4.0 refers to initial technological changes that then lead to deeper, more comprehensive economic and social transformations. In fact, this is what Schwab, K. (2016) refers to: namely, Industry 4.0 is no different than one of the manifestations of this revolution.

Although Industry 4.0 or the fourth industrial revolution had only begun to gain ground in recent years, still the available, mostly foreign literature is abundant. Various experts have studied the new industrial revolution in many different ways. However, they - probably due to the short time elapsed have only focused on the history of industrial revolutions, the interpretation of concepts and the role of the recent industrial revolution in industrial production, technical and technological, production organisation and structural issues, as well as, its impact on businesses (ZezulKa, F. et al. 2016; Devezas, T. et al. 2017; Reischauer, G. 2017; Ibarra, D. et al. 2018; Luthra, S. and MangLa, S.K. 2018). This is no coincidence, because changes, as ever in history and also now, have appeared in the industry first. Major transformation can also be expected in the field of - not in the order of importance - transport, energy, infrastructure, well-being (CAYLAR, P-L. et al. 2016; SAntos, C. et al. 2017). Moreover, all these changes will not leave the economic space intact, however, their manifestation will also be differentiated. Brettel, M. et al. (2014), who classified the publications of eight scientific journals based on three topics (individualized production, production network, end-to-end engineering in virtual process chain) and defined research directions within them, also demonstrated that greatest attention has been given to the industrial and production connections of new technologies in recent years.

At the same time, the examination of Industry 4.0 in a geographical context has received a more modest focus so far (NAGY, Cs. and Molnár, E. 2018; Nick, G. 2018; Nick, G. et al. 2019). This can be explained, among others, by the novelty nature of the phenomenon and by the fact that the spatial manifestation of the changes takes longer, and that some of them no longer occur in real space. In spite of this they (or at least part of them) will or can have spatial implications, but they render real space less relevant. Although the role of virtual world will increase and in the digital ecosystems different players get connected and do businesses (WINTER, J. 2020), this does not mean "the end of geography" (Tranos, E. and Nijkamp, P. 2013). The closer fusion of industrial production and ICT results in the interconnectedness and complex relationship between the real and virtual worlds in cyber-physical systems (IBARRA, D. et al. 2018). This presents another challenge to economic geography.

\section{Characteristics and conditions of ICT at enterprises}

There are a number of conditions for the implementation and fulfilment of Industry 4.0. One of these is the availability of the necessary ICT infrastructure because it is the backbone of a connected economy (BouÉE, C-E. and Schaible, S. 2015). Regarding info-communication tools, the computer is perhaps the most important and the Internet is also indispensable connecting virtual and physical systems and revolutionising the global value chain organisation (SсншАв, K. 2016). ICTs play a very important role not only in the development of individual enterprises but also in the development of the economy as a whole (Müller, J. M. et al. 2018). Over the last decade, the development of ICT infrastructure has also intensified in Hungary and demand for services that help the economy (mainly industrial production) or even the population in the digital transition has 
increased. This will have an impact on the global competitiveness of individual regions and countries (BARsI, B. 2003) and can have a positive impact on it, while there will be also marked changes in production, consumption and trade.

The speed and success of certain areas for the use of new technologies depends heavily on how enterprises are supplied with ICT and the readiness of the enterprises to use them. It is therefore not surprising that a number of recent studies addressed the digital maturity of businesses (Schmidt, H. 2014; CAYlar, P-L. et al. 2016). According to a survey by McKinsey \& Co. in 2016, which included more than 300 manufacturing professionals from Germany, Japan and the US, barely 16 per cent of industrial manufacturers had a comprehensive Industry 4.0 strategy and only 24 per cent indicated that efforts were made to work out one (CAylar, P-L. et al. 2016). The majority, however, are not prepared for the new technological revolution, therefore CAYLAR, P-L. et al. $(2016,7)$ laid out some key tasks (“... prioritize and scale up, adopt a test-and-learn approach, put foundations in place, treat data as a competitive advantage, work across functions and manage change the organisation ...") for companies to help them move forward in the fourth industrial revolution.

Sommer, L. (2015) called attention to that Industry 4.0 should be implemented successfully not only in large enterprises in Germany, but also in small and mediumsized enterprises, because both groups play a relevant role in employment. Furthermore, it is necessary to encourage the progress of small and medium-sized enterprises in Industry 4.0 because the interconnectedness of the economy only allows for a limited technological gap between small and large enterprises. If the digital gap between the two groups is too large, co-operation could be hindered. The experience of research in Hungary also supported the assumption that the chances and opportunities of large multinational companies and that of SMEs are not the same in Industry 4.0, although the latter also have advantages (e.g. organisational factors are less complex, lower profitability requirements, less technological dependence) compared to the former (HoRvátH, D. and Szaвó, Zs.R. 2019). However, if smaller businesses are unable to adapt to new challenges, they can easily become victims of the industrial revolution (SoMmer, L. 2015). And this danger is not only a threat to German SMEs, but also to Hungarian ones. Not only the size of companies but also the origin of their owner(s) can have relevant impacts on the process of Industry 4.0. The research carried out in Eastern Hungary in 2019 has proved that Industry 4.0 is more advanced in the companies with foreign interest (NAGY, Cs. et al. 2020).

Many factors limiting the realisation of Industry 4.0 have been identified in previous researches that, despite their diversity, can be divided into a number of major categories (e.g. inadequate qualification of human resources, technological, infrastructure deficiencies, scarce financial resources, organisational problems) (HoRváth, D. and Szabó, Zs.R. 2019). The weight of different factors is different depending on the size and sector of the enterprise. The lack of a well-qualified workforce is the most important limiting factor in the case of small and medium-sized enterprises, while in multinational companies organisational and technological factors are the most important. In many cases, Hungarian businesses also have problems with the lack of adequate ICT infrastructure or, even if available, it is not fully suited to make the transformation to Industry 4.0 (ERDEI, E. 2019). Other research emphasized the lack of human and financial resources in German businesses as an obstacle. These resources would be important because they could help companies to transform their internal structure, improving thereby the ability of businesses to receive new ICT (DIHK 2015). In the beginning many small and medium-sized enterprises lacked interest in Industry 4.0 in Germany partly because they did not see information security and data protection. And because of this lack of trust there was fear that the technological transfor- 
mation of the country will fall behind in the fourth industrial revolution (EISERT, R. 2014).

The largest global survey to date, involving 2,000 businesses from 26 countries in nine major industries emphasized that new technology is not the biggest challenge for companies, but the lack of the digital culture and qualification in the case of their workers necessary for implementing Industry 4.0, and this needs to be developed (Geissbauer, R. et al. 2016). According to a Czech survey in 2017 the lack of accurate information on the benefits of Industry 4.0 is also hampering the realisation of the fourth industrial revolution. This is why several companies in Czechia did not attach much importance to consider Industry 4.0 and to prepare for it, and in the long-term this could result in a serious lag in development (Kopp, J. and BASL, J. 2017). To avoid this, the EU and national governments help companies (mostly SMEs) and regions (mostly less developed) in different ways (funding, education) particularly from 2014 to be able to prepare for the digital transformation (NICK, G. 2018; BAILEY, D. and DE Propris, L. 2019; Šlander, S. and Wostner, P. 2019). In Hungary there also have been special strategy programs and several kinds of funds for supporting enterprises in the transition of Industry 4.0, particularly since 2016. But so far not so many enterprises have competed for those (NICK, G. 2018).

Although many German enterprises did not even know the concept of Industry 4.0 in 2014 (EISERT, R. 2014), in 2016 the results of the global survey showed that enterprises in Germany and Japan would be the most advanced among the countries in digitalisation within five years, while the same will be true for America among the continents in 2021 (Geissbauer, R. et al. 2016). Although the level of digitalisation may increase in the coming years, thus, globalisation as well, regional differences may remain significant depending on local conditions (Geissbauer, R. et al. 2016). It is particularly important to know the characteristics of each location (e.g. ICT infrastructure, qualification and capabilities of workforce), the social and economic environment of the enterprises there, as those can strongly determine the competitiveness of a given area (Šlander, S. and Wostner, P. 2019).

It is most likely that areas with more advanced economy and more advanced industry are in a better position from the view point of ICT infrastructure and application (Schwab, K. 2016; Luthra, S. and Mangla, S.K. 2018). A number of researches have now shown that there may be significant differences in the spatial distribution of ICT at different spatial levels (Grasland, L. and Puel, G. 2007). Within the EU Finland, Sweden, the Netherlands, Denmark and the United Kingdom are the leading, while Italy, Poland, Greece, Romania and Bulgaria are the tailenders following Hungary, despite a significant increase in e.g. internet access in countries in the latter group, for example, between 2010 and 2016 (DESI 2019). The close correlation between economic development (GNI/ person) and internet use was confirmed by our previous correlation study using the SPSS software. The Pearson correlation coefficient was 0.846 (BALOG, Zs. et al. 2018).

Digital development varies within countries as well. This may be due to a number of reasons (e.g. geographical location, social, economic, infrastructure, etc. factors), however, the fact that the needs of each industry for new technologies and their different digital development may also contribute to it. The industries that dominate the economy of a given area can have a strong impact on the digital maturity of enterprises there.

The geographical differences of industries may also have an impact on the spatial progress of Industry 4.0. Industry is one of those sectors of the economy where Industry 4.0 develops fast and it is much more advanced than in other industries like tourism or agriculture (Berta, O. 2018; DESI 2019). Thus, industry has its first benefit and positive impact (CAylar, P-L. et al. 2016; Geissbauer, R. et al. 2016). In line with international experiences, it can therefore be also assumed that industry is the sector in Hungary where the fourth industrial revolution is more advanced. Consequently, the spatial pattern of digital 
development may be closely related to the spatial concentration of industrial production (KIss, É. 2002, 2010). Its verification is also attempted in this study, while also exploring the spatial characteristics of the application of new technologies in Hungarian enterprises. Considering the theoretical foundations of the paper the main research question is how the "digital divide" relates to the "industrial divide" in the economic space of Hungary.

\section{Data and research methods}

This study is based on the analysis of the relevant literature and official statistical data and, as well as, the cartographic representation and evaluation of the rankings by county of various indicators. The geographical context was explored using two indicator systems: one related to ICT and the other to the industry. In both complex indicator systems there were several variables, which are detailed in the tables. Two groups were formed out of the 20 ICT indicators. The first group - "old" or traditional ICT indicators - included those that had a long history of statistics and a longer track record in operating enterprises (e.g. computers and the Internet). The so-called "new" ICT indicators (e.g. cloud service, 3D printing) have started to spread in businesses in recent years and can be more directly linked to Industry 4.0. Only a few of the studied ICT indicators - due to length limitation - are presented (in four figures) with the most significant regional differences and which are more representative of industrial enterprises. Ten indicators were used to illustrate the regional differences in the Hungarian industry.

The selected indicators included extensive and intensive ones as well. The former represents the amount and size of the elements of a factor (e.g. number of enterprises), while the latter are weighted averages obtained by the merging of the elements (e.g. computer per 1,000 enterprises).

Necessary data on the info-communication capabilities of enterprises, i.e. the database of the study, were provided by accessible official statistical data with a county breakdown (NUTS-3 level) for 20 regional units (the capital Budapest and 19 counties). The novelty of the topic is also shown by the fact data collection of many ICT indicators, especially in the case of the new ones, has only started in recent years. Therefore, the focus was on static rather than dynamic analysis due to the lack of longer time series. For each indicator only the most recent available data were used. The one to two-year difference in the year of origin of the data did not hinder the interpretation of spatial differences.

ICT data were only available by counties, as data by settlements would have allowed the identification of certain large companies, and this is not permitted by the Data Protection Act. Considering its content, the information and communication (IC) industry comprises three different levels of network: physical infrastructure, the services they create and their use (Houzet, S. 2007). These levels are also represented by the ICT indicators selected to identify spatial differences.

Since the studied ICT data cover all Hungarian enterprises, they only provide indirect information about the industry, which accounted for 9.2 per cent of all corporate businesses in Hungary in 2018. (Industry is the secondary sector of the economy and includes mining, manufacturing and electricity generation, gas, steam and water supply.) This is a very low value, but if we look at the importance of industry, e.g. based on its share of gross value added, a much higher value $(58.7 \%)$ is obtained compared to other economic sectors. Industry concentrates 11.4 per cent of working companies with foreign interest (more than 2,500 enterprises). This is worth mentioning because multinational enterprises tend to have better digital preparedness (NAGY, Cs. et al. 2020) and because they also played a decisive role in shaping the spatial pattern of the industry (KIss, E. 2002, 2010).

Studying the spatial structure of ICT and industry was supported by summarizing the 
county rankings of the various indicators. The data for each indicator were available for 20 regional units and their values were indicated by ranking numbers from 1 to 20 . Number 1 referred to the most favourable area regarding the given indicator, while 20 was the most unfavourable position. If the value of the indicator of two spatial units was the same, they were given the same rank number. The cumulative rank that is generated by aggregating the rank numbers is a complex indicator that reveals geographical characteristics. The "old" and "new" of ICT indicators were also plotted separately based on their cumulative rank due to their spatial characteristics. Then a figure showing the rank numbers of all ICT indicators were created. Based on it, the regional types of the digital advance of Hungarian enterprises can be clearly determined.

The figure of the spatial structure of the industry based on the cumulative rankings of the county values of the industrial indicators was compared with that of the ICT to reveal the spatial similarities and differences and to answer the question whether the spatial patterns of industrial and digital maturity are closely intertwined or not.

\section{Regional differences in information and communication technologies}

\section{Old indicators}

Counties with favourable and unfavourable positions can now be clearly distinguished based on the ranking number of the values of the following ten old ICT indicators (ICTo):

ICTo-1: Number of IC enterprises per 1,000 enterprises in 2018;

ICTo-2: Number of IC employees per 1,000 employees in 2018;

ICTo-3: Use of personal computers and work stations in enterprises in 2018, \%;

ICTo-4: Use of internet in enterprises in 2018, \%;

ICTo-5: Number of computers per 1,000 enterprises in 2017;
ICTo-6: Ratio of large computers within the computer equipment of enterprises in 2017, \%;

ICTo-7: Ratio of employees using computers in enterprises in 2016, \%;

ICTo-8: Ratio of employees using internet in enterprises in 2016, \%;

ICTo-9: Ratio of employees using mobile web in enterprises in 2016, \%;

ICTo-10: Ratio of enterprises providing remote access for their employees in 2016, \%.

If a county has got several low rank numbers, it means that the county is in a good position in the supply of different old ICT (Table 1).

The number of information and communication enterprises is important because they provide essential services to businesses in other fields of the economy thereby they contribute to the realisation of Industry 4.0 and - in wider sense - the fourth industrial revolution. In 2018 there were more than 64,000 IC enterprises operating in Hungary and their national average was 36 IC enterprises per 1,000 enterprises. However, the county average was everywhere below the national average except for the capital city and Pest county. This can be explained by less favourable conditions of factors attracting IC enterprises (e.g. technological background, infrastructure development, economic environment, market size, social factors, workforce training, cultural milieu) (Kanalas, I. 2004). In 2018, 63 per cent of the enterprises of the IC industry were concentrated in the region of Budapest, in contrast, in Békés, Jász-Nagykun-Szolnok or SzabolcsSzatmár-Bereg counties only one to two per cent. The spatial pattern of the employees of IC industry is similar to this. The high value of Budapest (361 people per 1,000 employees) can be explained primarily by the size of the city and its central role in the country, among many other factors. According to a research, the classification of towns of the Hungarian town network into IC types depends most on the size, historical traditions, economic, administrative role and geographical location of the town (Rechnitzer, J. et al. 2003). 


\begin{tabular}{|c|c|}
\hline 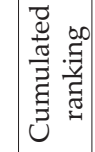 & 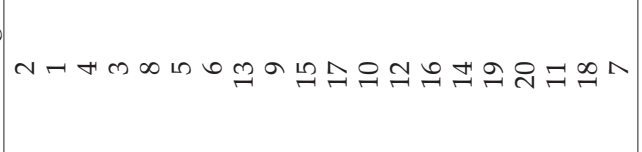 \\
\hline $\begin{array}{l}0 \\
\stackrel{1}{0} \\
\text { ํํㄴ }\end{array}$ & 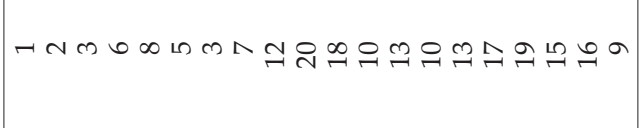 \\
\hline$\stackrel{a}{\grave{c}}$ & 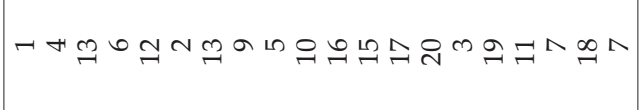 \\
\hline $\begin{array}{l}\infty \\
\vdots \\
\varrho \\
\varrho\end{array}$ & $\neg$ - \\
\hline$\hat{o}$ & 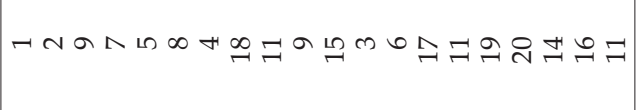 \\
\hline 号 & 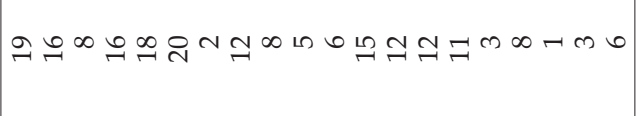 \\
\hline$\stackrel{\varphi}{0}^{\underline{\varphi}}$ & ーレ \\
\hline 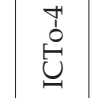 & 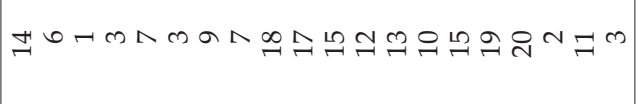 \\
\hline$e^{0}$ & 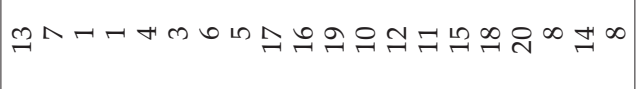 \\
\hline$\tilde{U}^{\tilde{U}}$ & 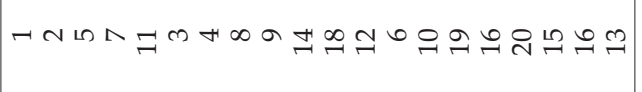 \\
\hline$\stackrel{\overrightarrow{0}}{\varrho}$ & 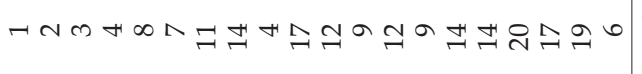 \\
\hline $\begin{array}{l}\overrightarrow{0} \\
0 \\
0 \\
0 \\
\overrightarrow{0} \\
\overrightarrow{0} \\
0 \\
0\end{array}$ & 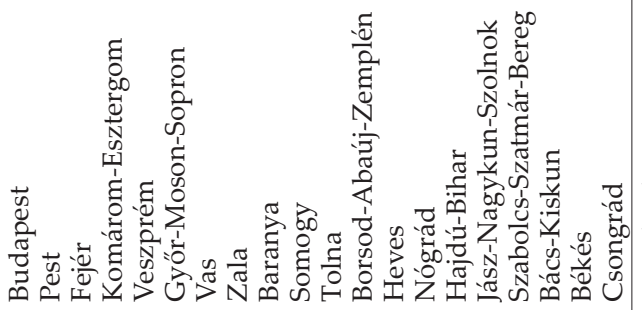 \\
\hline
\end{tabular}

As computers became widespread their use and that of the Internet by enterprises is already common today. In 2018, over 90 per cent of enterprises in all counties use computers, and the use of the internet fell short of 90 per cent in only a few counties (e.g. Jász-NagykunSzolnok, Szabolcs-Szatmár-Bereg) suggesting small regional differences. In terms of both indicators, Fejér county was at the forefront because the ratio of enterprises using computers (96\%) and the Internet (93\%) was the highest there. Computers are used for different purposes, but there are not relevant differences by county in the ways how they are being used. The most often (in the $50-60 \%$ of Hungarian companies) computers are used for emailing while in 25-35 per cent of companies for administrative tasks. The applications of software are the most rarely, only 10-20 per cent of enterprises use those.

In Hungary, there were more than 1.3 million computers in enterprises with more than $10 \mathrm{em}$ ployees in 2018. On average 779 computers were used per 1,000 enterprises, with more than double that value in the capital city $(1,733)$. The outstandingly high number is the result of a particularly high spatial concentration $(41 \%)$ of businesses. In the northern counties of Transdanubia, the number of computers was between 700 and 900 per 1,000 enterprises. Worst computer supply was found along the southern and eastern borders, as well as in Nógrád county, where only a quarter of businesses had computers. The reasons can be found in the socio-economic conditions of the counties with roots dating back long in history (Figure 1). 


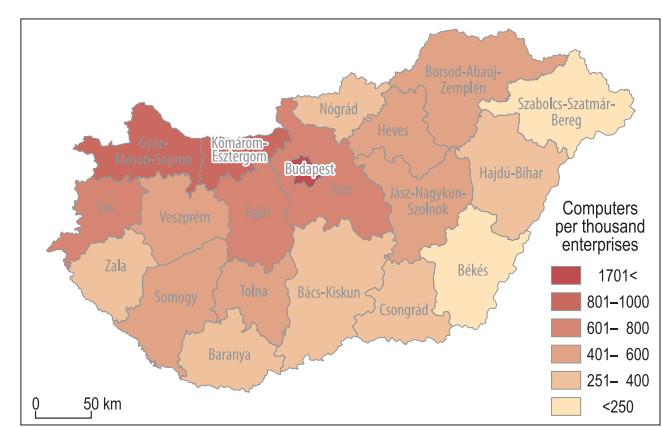

Fig. 1. Number of computers per 1,000 enterprises by county in Hungary, 2017. Source: Data of Hungarian Central Statistical Office.

The ratio of large computers within all computers of enterprises has a very specific spatial structure, because it is almost the opposite of computers per 1,000 inhabitants. The latter has reached a considerable number in the northern half, while the former has high numbers in the southern part of the country. According to the definition of the Statistical Office large computers are nonportable computers or, alternatively, computers longer than $50 \mathrm{~cm}$ in all directions. This suggests that large computers are more common in certain industries and in larger enterprises. Their share reached the highest level (75\%) in Bács-Kiskun county, followed by Vas and Jász-Nagykun-Szolnok counties with 60 per cent and 59 per cent respectively. This is mainly due to the car manufacturers and/or their suppliers there.

The share of employees using computers in businesses is now surely much higher than it was in 2016. Fewest employees worked with computers at their workplace in SzabolcsSzatmár-Bereg county (31\%) and the most in the capital city (58\%), however, in the vast majority of the country their proportion varied around 35-38 per cent, that is below the national average (45\%). The ratio of employees using computers is especially high in the northern part of the country, North of the Nagykanizsa-Dunaújváros-Tiszaújváros line (Figure 2).

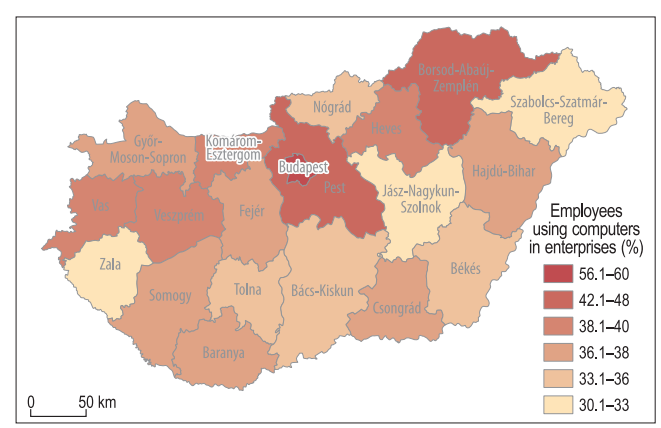

Fig. 2. Ratio of employees using computers in enterprises by county in Hungary, 2016. Source: Data of Hungarian Central Statistical Office.

On average, one in four employees used the internet in enterprises in 2016, and this has certainly improved since then. The situation is more favourable only in the capital city with almost one in three employees used computers. The value of this indicator was also high (23-25\%) in Baranya, Hajdú-Bihar and Csongrád counties, which are important higher education centres. Even in Jász-NagykunSzolnok county with the lowest value (17\%) only a few per cent fewer people used the internet in enterprises indicating not marked spatial differences. In Slovakia, low ratio of internet availability has been identified as an indicator of periphery situation, which has shown close connection with some economic and social-demographic periphery indicators (Rosina, K. and Hurbánek, P. 2013).

A few years ago mobile internet was used by 11 per cent of employees in businesses. In 2016, enterprises in the belt from Nógrád county to Békés county except for Heves county were in the worst situation, where only a few percent of workers used mobile internet. This can also be attributed to the unfavourable overall social and economic development of the region. GDP per capita was also among the lowest in this region in 2017, reaching 43-65 per cent of the national average.

The share of enterprises providing remote access to workers is highest in the capital city $(60 \%)$ and in its region (51\%) which can be 
attributed mainly to the importance of the service sector. This type of work is not typical for workers in the industry or directly in production. The ratio of such enterprises is also high in Northern Transdanubia. In the eastern and southern part of the country, however, this value is well below the national average $(48 \%)$ for probably a number of reasons (e.g. less remote working, less trust in it, industrial affiliation of enterprise).

\section{New indicators}

The first data available on the application and spreading of new technologies in Industry 4.0 are from 2018 and show that they are not very common yet. This is also supported by experience in the EU. Digital technologies (e.g. electronic exchange of information, social media, cloud services, online trading) were integrated by small ratio of enterprises in Hungary (5-15\%) in 2019. Therefore, Hungarian companies were among the worst performers regarding EU member states (DESI, 2019). Based on the index measuring the development of digital economy and society (Digital Economy and Society Index - DESI), Hungary is $23^{\text {rd }}$ among the 28 member states of the EU between 2017 and 2019 (DESI, 2019). (DESI includes the following indicators: connectivity, human capital, use of internet services, integration of digital technology, digital public services.) Although the country's digital development has improved over this period (from $40 \%$ to $45 \%$ ), it is still below the EU average (53\%).

Consequently, counties with favourable and unfavourable positions can be also distinguished based on the ranking number of the values of the following ten new ICT (ICTn) indicators:

ICTn-1: Purpose of mobile web use: use of software application, as a percentage of enterprises in 2018;

ICTn-2: Ratio of enterprises using cloud based services in 2018, \%;

ICTn-3: Cloud based service: use of Customer Relationship Management (CRM) application, as a percentage of enterprises in 2018, \%;

ICTn-4: Ratio of enterprises using service robots in 2018, \%;

ICTn-5: Ratio of enterprises using industrial robots in 2018, \%;

ICTn-6: Ratio of enterprises using their own 3D printer in 2017, \%;

ICTn-7: Ratio of enterprises where 3D printing was used for the following purposes: manufacturing moulds, tools, parts, semi-finished products for sale in 2017, \%; ICTn-8: Ratio of enterprises using 3D service provided by other enterprises in 2017, \%;

ICTn-9: Ratio of enterprises performing Big Data analysis: with their own employees in 2017, \%;

ICTn-10: Ratio of enterprises performing Big Data analysis: with external, outside the enterprise, service providers in $2017, \%$. The use of new ICTs has reached mostly only a few per cent, however, their spatial distribution is characterised by some sharp and unconventional differences (Table 2).

Only two of the new ICT indicators had relatively high values: namely, the number of enterprises using mobile internet for software applications and that of enterprises using cloud-based services. Values of the former indicator varied between 10.6 per cent (Szabolcs-Szatmár-Bereg county) and 23.8 per cent (Budapest), while in the case of the latter values ranged from 10.2 per cent (Békés county) to 24.7 per cent (Budapest). Enterprises using mobile internet for software were more abundant in the northern part of Transdanubia, the capital city region and in Northern Hungary, while those using cloud based service were more concentrated in a couple of areas (Budapest, Baranya, Somogy and Pest counties).

The lowest values (usually 1\% or less) were in the use of service robots, i.e. this is the least prevalent in the counties. Only a fraction of enterprises used service robots. The share of such enterprises was the highest (1.3\%) in Győr-Moson-Sopron county in 2018. At the same time, industrial robots were used in a higher ratio (2-6\%). 


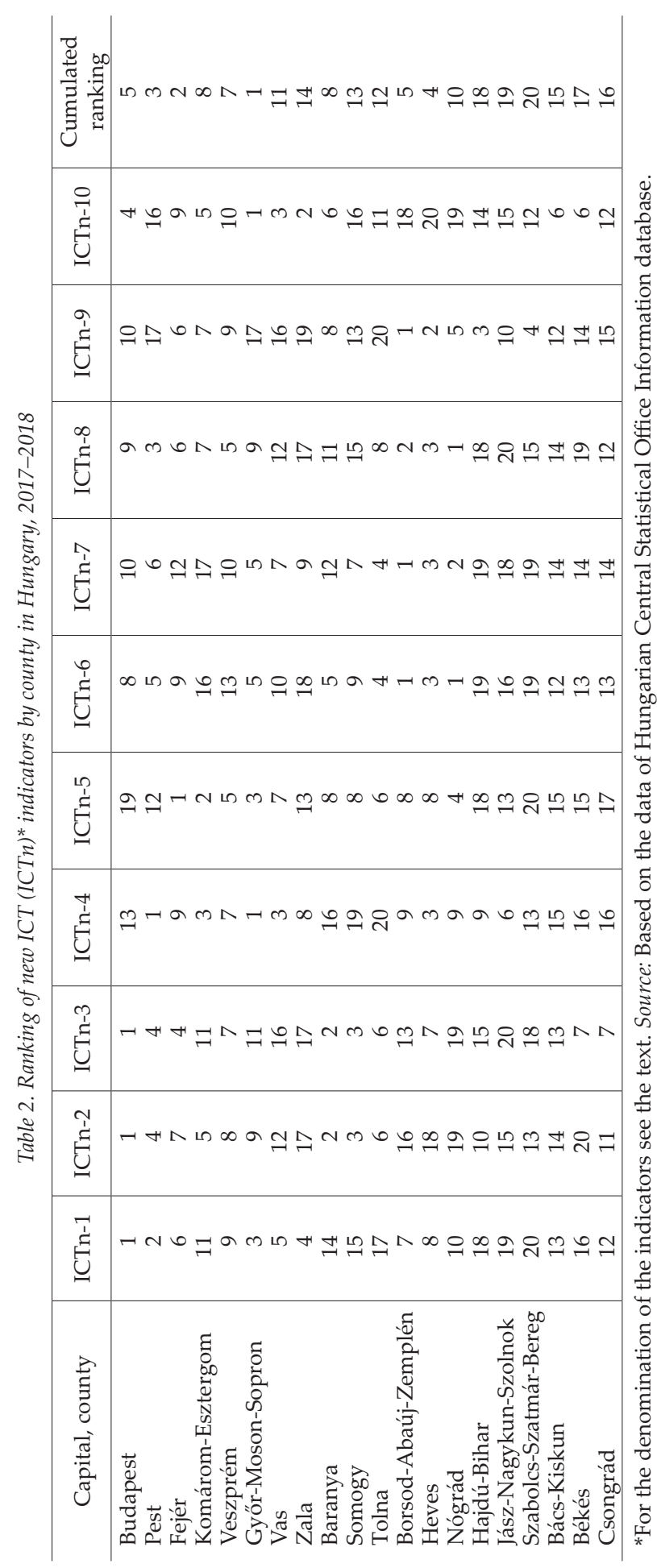

Generally, robots perform work that, for example, involve heavy physical work, may have negative health effects, require high accuracy or it is quite monotonous work. Automotive industry is the primary user of robots, which is followed by electronics, metal industry, chemicals and food industry (NagY, Cs. and Molnár, E. 2018). As a consequence, the spatial pattern of industrial robots is closely connected to these branches. Most of the enterprises using industrial robots can be found in Northern Transdanubia (Fejér 5.7\%, Komárom-Esztergom 5.6\%, Győr-Moson-Sopron 5.3\% and Nógrád county $5.2 \%$ ) related to the significant industrial activity there (Figure 3).

3D printing has only started to spread in Hungary lately. It is popular in manufacturing industry where the basic purpose is to manufacture moulds, tools, parts, etc. for sale. The share of enterprises using 3D printing was also characterised with very low values except for three counties (Borsod-Abaúj-Zemplén, Heves and Nógrád), which constituted one of the pillars of the former socialist heavy industry. $3 \mathrm{D}$ printing is most widespread in enterprises in the above counties, however, only in a very low per cent (1.9-2.2\%) of the enterprises (Figure 4).

The values of other ICT indicators (e.g. Big Data analysis) varied mostly between 2 and 6 per cent, indicating the early stages of digital transformation in enterprises. However, depending on their industrial affiliation values show smaller or greater variation. The level of the appli- 


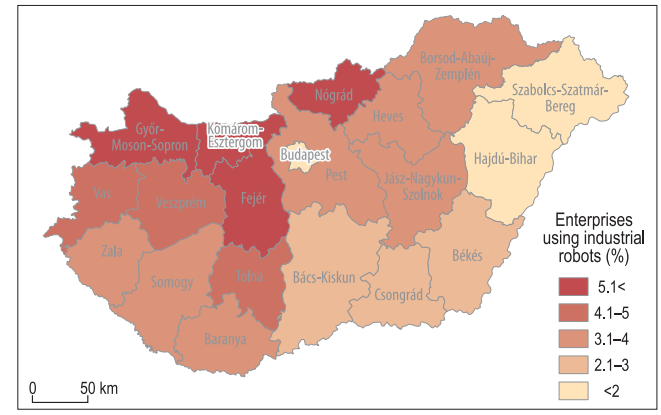

Fig. 3. Ratio of enterprises using industrial robots by county in Hungary, 2018. Source: Data of Hungarian Central Statistical Office.

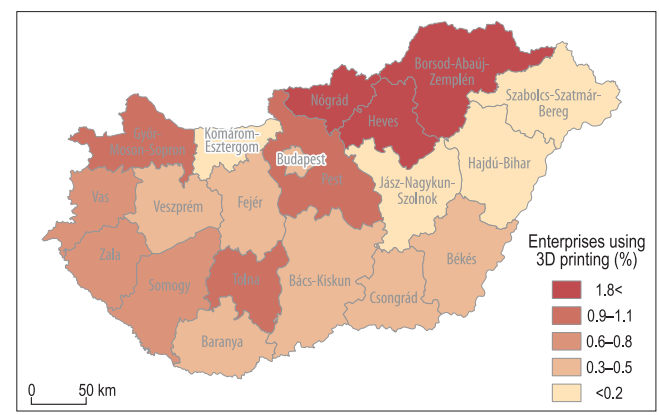

Fig. 4. Ratio of enterprises by county in Hungary where 3D printing was used for the manufacturing of moulds, tools, parts, semi-finished products for sale, 2017. Source: Data of Hungarian Central Statistical Office.

cation of new technologies in industrial and manufacturing enterprises is usually higher than in the economy as a whole (Table 3).

According to the empirical research carried out in Eastern Hungary in 2019 there are considerable differences between Hungarian and foreign-owned enterprises in the advancement of Industry 4.0 (NAGY, Cs. et al. 2020). Usually enterprises with foreign interest are those where on the one hand the application of new technologies is more frequent, on the other hand several kind of new technologies are applied. Although Hungarian enterprises are interested in new technologies, they have applied only a few of them, mostly robots and $3 \mathrm{D}$ printers. The reasons for this (e.g. lack of money and skilled workers, less developed organisational structure) are very similar to the results of other researches (e.g. (Horváth, D. and Szabó, Zs.R. 2019).

\section{Geographical types of ICT development}

The ranking based on the cumulative ranks of the "old" and "new" indicators of ICT shows that older info-communication technologies are particularly significant in the region of the capital city and in Northern Transdanubia and Csongrád county (Figure 5 and 6).

The geography of more recent ICT shows a stronger North-South divide. At the same

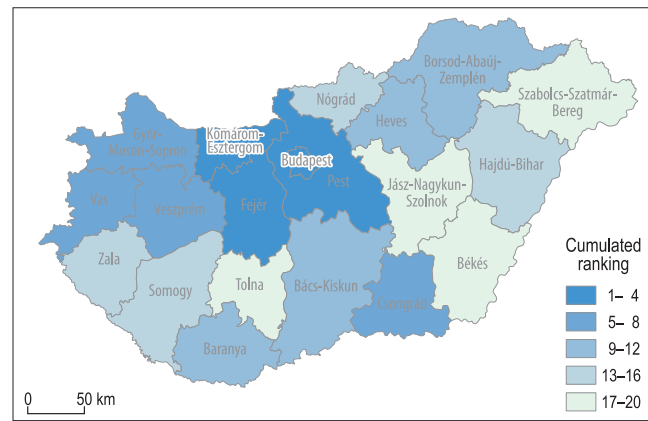

Fig. 5. Cumulated ranking of old ICT indicators by county in Hungary. Source: Based on Table 1.

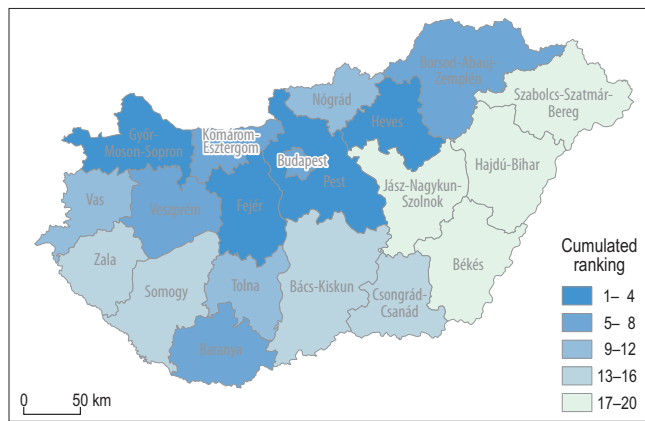

Fig. 6. Cumulated ranking of new ICT indicators by county in Hungary. Source: Based on Table 2. 
Table 3. Use of ICT in Hungarian enterprises*, 2018

\begin{tabular}{l|c|c|c}
\hline \multicolumn{1}{c|}{ Denomination } & $\begin{array}{c}\text { Manufacturing, } \\
\%\end{array}$ & $\begin{array}{c}\text { Industry, } \\
\%\end{array}$ & $\begin{array}{c}\text { All sectors } \\
\text { of national } \\
\text { economy, } \%\end{array}$ \\
\hline $\begin{array}{l}\text { Enterprises with fixed broadband internet con- } \\
\text { nections }\end{array}$ & 84.6 & 91.0 & 82.7 \\
$\begin{array}{l}\text { Ratio of enterprises with mobile broadband } \\
\text { Connections }\end{array}$ & 72.0 & 81.2 & 70.8 \\
$\begin{array}{l}\text { Purpose of mobile web use: access to the e-mail } \\
\text { system of the enterprise }\end{array}$ & 64.1 & 73.7 & 62.6 \\
$\begin{array}{l}\text { Purpose of mobile web use: access to documents } \\
\text { Purpose of mobile web use: using software }\end{array}$ & 33.9 & 42.1 & 36.5 \\
$\begin{array}{l}\text { applications } \\
\text { Ratio of employed informatics professionals }\end{array}$ & 27.7 & 38.5 & 19.3 \\
Cloud based service: use of CRM application & 3.2 & 3.3 & 26.1 \\
Ratio of enterprises using cloud based services & 17.2 & 22.7 & 4.9 \\
\hline
\end{tabular}

*Enterprises employing more than 10 people. Source: Data of Hungarian Central Statistical Office Information database.

time, in the eastern and southern counties of Hungary (with the exception of Baranya county) the digital transformation of enterprises is much less favourable which can be related to the historical past, the disadvantages of the starting conditions, lower economic performance, periphery location, etc. After 1989 these regions were not very attractive targets for foreign investors and their deindustrialisation was intensive. All these led to that they fell behind in development in last decades. Moreover, the eastern-southeastern parts never belonged to the more developed regions of the country. Even today this is the semi-periphery of the EU, while the southwestern part has become a "lock-in" area which hardly finds the way out.

By forming a cumulative ranking based on the rankings of all ICT indicators the final ranking of the counties has been established reflecting the degree of progress of each region and the enterprises there, i.e. how they perform in the supply and application of info-communication tools and technologies. Based on the ranking, five main types can be identified, where the spreading of ICT and digitalisation are:

1. Well-advanced: Pest, Győr-MosonSopron and Fejér counties, and Budapest;

2. Advanced: Komárom-Esztergom, Vas, Borsod-Abaúj-Zemplén and Veszprém counties;
3. Moderately advanced: Heves, Baranya, Csongrád and Nógrád counties;

4. Less advanced: Bács-Kiskun, Zala, Somogy and Tolna counties;

5. Least advanced: Hajdú-Bihar, Békés, Jász-Nagykun-Szolnok and SzabolcsSzatmár-Bereg counties (Figure 7).

Areas in the first group of categories are the leading ones, while the fifth group leads the army. The two extremes in space are the region of the capital city, together with Northern Transdanubia and Northern Great Plain. In a different way, there is a North-

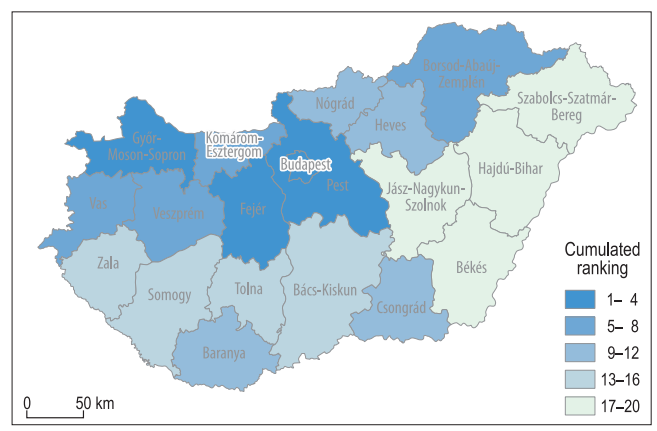

Fig. 7. Cumulated ranking of all ICT indicators by county in Hungary. Source: Based on the Table 1 and 2. 
South divide in the spreading of Industry 4.0, as the degree of the digital transformation of the enterprises is better in the North and poorer in the south. Attention should be drawn, however, to the fact that the digital maturity of the population and enterprises of the counties may vary considerably (BALOG, Zs. et al. 2018; NedelKA, E. 2019). There is no doubt that greater IC preparedness of the population can have a positive impact on the supply and application of infocommunication technologies and tools contributing thereby to the improvement of the economy and the competitiveness of the given area.

\section{Spatial connections between ICT and industry}

Following the regime change, radical changes took place in the Hungarian industry, which also manifested in space (KIss, É. 2002). The process of deindustrialisation was very strong in the 1990s, while a number of new investments were made forming a new spatial structure of the industry based primarily on foreign capital. This was modified by reindustrialisation by today. Cumulative rankings calculated based on the rankings of the variables of industry in 2018 clearly show the importance of industry in each county and their position in the whole country (Table 4). The following industrial indicators (IndI) were used:

IndI-1: Number of industrial enterprises in 2018;

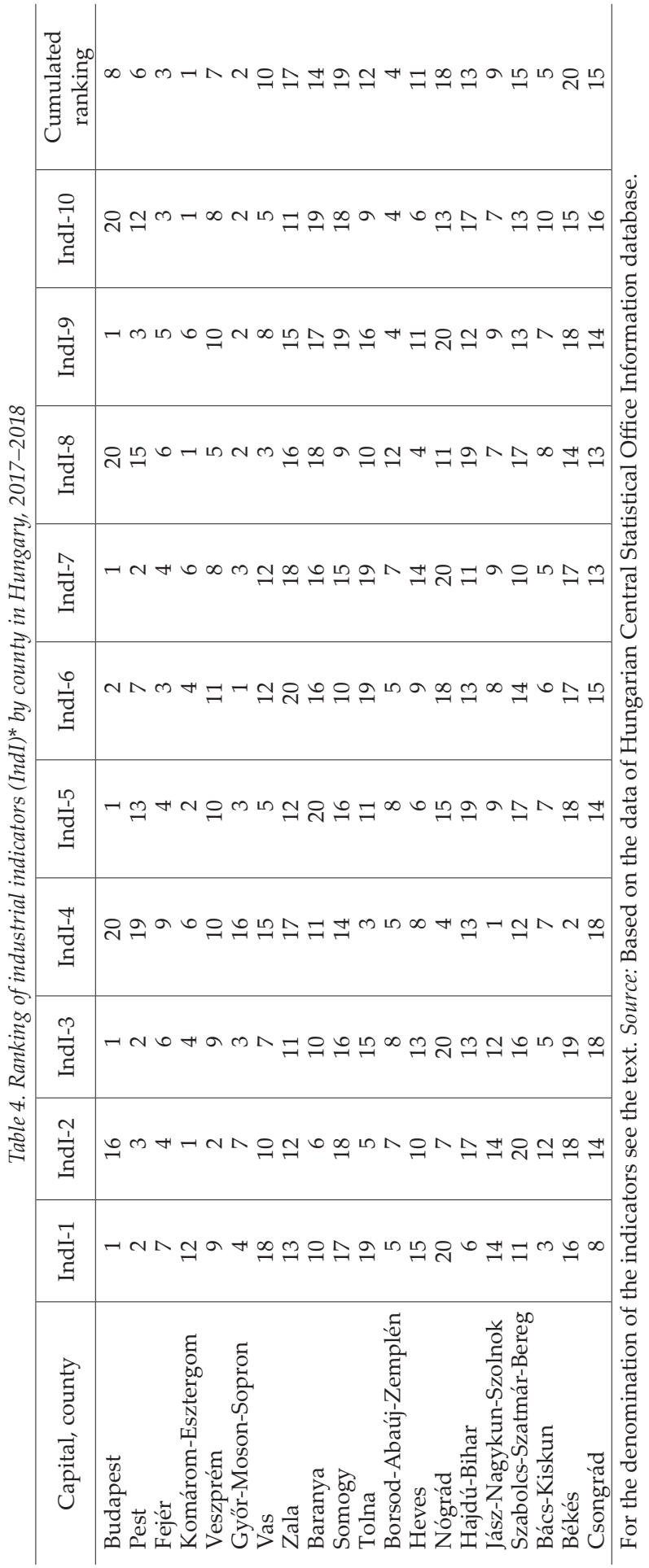


IndI-2: Ratio of industrial enterprises of all enterprises in 2018, \%;

IndI-3: Number of enterprises with foreign interest in manufacturing in 2017;

IndI-4: Ratio of manufacturing enterprises with foreign interest of all enterprises with foreign interest in 2017, \%;

IndI-5: Value of industrial production per inhabitant in 2018, 1,000 HUF;

IndI-6: Export sales of industry in 2018, million HUF;

IndI-7: Number of employees in industry in 2018;

IndI-8: Ratio of industrial employees of all employees in 2018, \%;

IndI-9: Gross value added of industry in 2017, million HUF;

IndI-10: Share of industry of total gross value added in 2017, \%.

Cumulative rankings provide a good basis to identify areas where industry is more important in the economy and where it is less so. The main types of counties are the following, where industry is:

1. Very significant: Komárom-Esztergom, Győr-Moson-Sopron, Fejér and BorsodAbaúj-Zemplén counties;

2. Significant: Bács-Kiskun, Pest, Veszprém counties and Budapest ;

3. Moderately significant: Jász-NagykunSzolnok, Vas, Heves and Tolna counties;

4. Less significant: Hajdú-Bihar, Baranya, Szabolcs-Szatmár-Bereg and Csongrád countie;

5. Least significant: Zala, Nógrád, Somogy and Békés counties (Figure 8).

The current spatial structure of the industry has many similarities to the spatial structure developed in the second half of the 1990s (KIss, E. 2002). After the regime change, in the $20^{\text {th }}$ century, the focus of industrial production shifted to the northern part of Transdanubia, because the NE-SW industrial axis, built on the resources of the mountains during the socialism, took up a direction of NW-SE. Foreign capital investments played a leading role in the development of the new industrial district (KIss, E. 2007). By today, the industry has continued to develop and expanded in space as a result of re-industrialization.

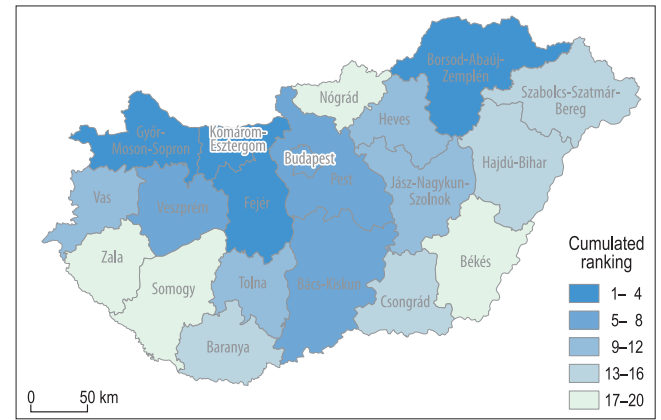

Fig. 8. Cumulated ranking of industrial indicators by county in Hungary. Source: Based on Table 4.

Industry remains relevant in Győr-MosonSopron, Komárom-Esztergom and Fejér counties, which, together with Vas county, form a group of FDI-based processing industrial counties (Lengyel, I. and VARgA, A. 2018). Many of the industrial indicators (e.g. share of gross value added, share of industrial employment, value of industrial production) have favourable values in these counties, and though they change somewhat each year they do not influence significantly the position of counties. They basically occupy a permanently relevant place in the Hungarian industry (Nemes NagY, J. and Lőcsei, H. 2015).

Industrial activity is also significant in the central part of the country, in the capital city, in Pest and Bács-Kiskun counties. Although Budapest is still the largest industrial centre in Hungary, its industry has lost weight after 1989, because many industrial facilities ceased to exist, were restructured and other sectors developed more dynamically (KIss, É. 2010). Industry has strengthened due to the investments of the Mercedes car factory and its suppliers in Bács-Kiskun county, and it took a prominent position in Hungary's industry in 2018: based on e.g. the number of industrial enterprises $(4,681)$, the ratio of industrial enterprises with foreign interests $(31 \%)$ or the number of industrial employees (45,000 people). In the last decade, the industry of Borsod-Abaúj-Zemplén county also becomes more significant and together with 
Bács-Kiskun, Veszprém, Heves and JászNagykun-Szolnok counties they form the group of reindustrialising counties (LENGYEL, I. and VARGA, A. 2018). In contrast, the importance of the industry of Northern Great Plain and Southern Transdanubia decreased, because of the reasons mentioned above, and today, the values of the counties there are mostly among the poorest ones. However, based on their ICT cumulative rank their position in the ranking is often even less favourable which can also have a negative impact on the regional development (BAILEY, D. and De Propris, L. 2019).

Comparing the spatial structure of industry and ICT, the spatial distribution of the two phenomena shows no close correlation. Only one quarter of the studied 20 spatial units can be classified into the same group based on the rankings of both indicators. (Therefore, the trial factor analysis did not produce any meaningful results beforehand - Nedelka, E. 2019.) There are only two counties (Fejér, Győr-Moson-Sopron), where both industry and ICT are most advanced, and one county (Békés) where the situation is most unfavourable based on the cumulative ranking of both indicators. The former ones belong to the most developed (industrialized) regions of the country with excellent supply by ICT while the latter one was previously classified as "Rural" (Lengyel, I. and VARGA, A. 2018) that generally includes counties that are far away from the centres mostly along the borders. Either their economic development or their social characteristics are considered, they often belong to the tailenders. For example, in 2017, the GDP per capita of Békés county reached only 59 per cent of the national average, but the share of its industry $(1.8 \%)$ regarding the gross value added was well below that of Győr-MosonSopron $(11.9 \%)$ or Fejér $(7.9 \%)$ counties. In addition to the counties at the two extremes, Veszprém and Heves counties were part of the same group considering both indicators. The former can be characterised by a relatively developed industry and advanced digital transformation, while the latter belonged to the midfield. The significance of the two indicators differs in the rest of the counties: either the weight of the industry or the degree of digital progress provides a higher ranking.

\section{Conclusions}

Following the latest economic crisis those involved in the global economy, enterprises in Hungary and abroad have to face another challenge, Industry 4.0 and/or the fourth industrial revolution. In this study the characteristics of ICT giving the basis of the new trends and their application are examined in geographical terms in relation to the spatial structure of Hungarian industry.

Depending on the geographical location of enterprises marked differences may be found in the supply of old and new ICT. The reasons for this can be very diverse, however, they can be explained mainly by the nature of the local social and economic environment. History, infrastructure development, transport links, qualification and skills of human resources, etc. are important. The peculiar path of development and the past of each area have a major impact on the current ICT maturity of the given place and the enterprises there. Dependence on the past, on the starting conditions, or in other words "path dependency" also prevails here to some degree it identifies the path of development and determines current differences.

Comparing the geography of the two phenomena, ICT and industry, it can be concluded that the spatial match is relatively modest. Thus, the degree of ICT progress cannot be closely linked to industry. ICT indicators follow a characteristic North-South divide, but industry shows no sign of such spatial regularity caused partly by reindustrialisation in the last decade. Digital divide and industrial divide do not match. This is primarily due to the spatial distribution of the older ICT indicators, as newer technologies are more closely linked to industry. In the digital transformation, counties and enterprises in Northern Great Plain are the least advanced, 
and this could lead to serious disadvantages in the long-term. Therefore, areas where ICT indicators are still unfavourable require further investment and improvements. Probably the available special funds of the EU and the government will help in this. In the future the digital development will play a much more important role not only in social and economic, but also in regional development.

The comparison of the spatial pattern of ICT and industry has also shown that the latter one plays an important role in the spreading of ICTs, but it is not enough in itself. Other (social, economic etc.) factors are also necessary for the application of IC technologies, tools or services by as many enterprises as possible. This can also explain that the spatial distribution of ICT and industry is different and that the industry is more significant in more counties, or in another way, the prevalence of ICT in space is more concentrated. In these counties, industry also plays a prominent role in the application of ICT, however, the social and economic environment, the qualification and skills of workforce, the financial resources and possibilities of enterprises, the general development of infrastructure, geographical location and many other conditions (e.g. different financial supports) are also favourable or relatively favourable for Industry 4.0 to progress. In fact, the more modest scale or the lack of the former conditions causes that digital transition is less advanced in many counties.

The study is essentially related to the first phase of a multi-year project. It can be seen as a kind of introduction, partly to the geographical examination of Industry 4.0 and partly indirectly to the spatial research of the digital maturity of the industry, which, in theory, has several ways to be continued. One way is a deeper analysis of the social and economic causes of spatial differences, the exploration of local peculiarities. This is necessary in order to define precisely what needs to be done in the area in order to mitigate the unfavourable conditions and to reduce regional differences. Another possible research direction is a stronger focus on the
ICT maturity of industrial enterprises at local and regional level, paying particular attention e.g. to the size structure of enterprises and to sectoral differences. Both research options require the promotion of empirical studies, as the range of official statistics is very limited. Furthermore, to reveal the spatial pattern of the financial supports what Hungarian enterprises have gained to promote their digital transformation would be also an interesting research direction. However, concerning the current Covid-19 pandemic a new research idea may come to the front in the near future, namely to study its impact on the process of Industry 4.0.

Acknowledgements: The authors acknowledge the financial support of the National Research, Development and Innovation Office (project number: K125091). Thanks are also due to the referees for their helpful comments and suggestions.

\section{REFERENCES}

Авоnyi, F. and Miszlivetz, F. 2016. Hálózatok metszéspontjain. A negyedik ipari forradalom társadalmi kihívásai (At intersections of networks. Societal challenges of the fourth industrial revolution). KőszegSzombathely, Savaria University Press.

BAILey, D. and De Propris, L. 2019. Industry and regional disparities and transformative industrial policy. In Revitalising Lagging Regions: Smart Specialisation and Industry 4.0. Regional Studies Policy Impact Books 1. (2). Eds.: Barzotto, M., Corradini, C., FaI, F.M., LABORY, S. and TomLinson, P.R., Brighton, UK, RSA, 67-78. Doi: 10.1080/2578711X.2019.1621102

BAlog, Zs., Kiss, É. and NedelkA, E. 2018. A negyedik ipari forradalom jelenségének vizsgálata az Európai Unióban (Investigating the fourth industrial revolution in the European Union). In Tehetség a tudományban. Ed.: Koloszár, L., Sopron, Soproni Egyetemi Kiadó, 49-63.

BARsi, B. 2003. Az információs és kommunikációs technológiák hatása a versenyképességre (Impacts of information and communication technologies on competitiveness). Tér és Társadalom 17. (3): 183-198. Doi: 10.17649/TET.17.3.907

Bartodziej, C.J. 2017. The Concept Industry 4.0. An Empirical Analysis of Technologies and Applications in Production Logistics. Berlin, Springer Gabler.

Berta, O. 2018. Információs technológiák használata a magyar mezőgazdasági vállalkozások menedzsmentjében: avagy egy digitális agrárgazdasági kuta- 
tás eredményei (The use of information technologies in the management of Hungarian agricultural enterprises: results of a digital agro-economic research). Gazdálkodás: Scientific Journal on Agricultural Economics 62. (4): 337-352. Doi: 10.22004/ag.econ.276215

Bouée, C-E. and Schaible, S. 2015. The Digital Transformation of Industry. Munich, Roland Berger Strategy Consultants/BDI.

Brettel, M., Friederichsen, N., Keller, M. and Rosenberg, M. 2014. How virtualization, decentralization and network building change the manufacturing landscape: an Industry 4.0 perspective. International Journal of Information and Communication Engineering 8. (1): 37-44. Doi: 10.1016/j.procir.2015.02.213

Caylar, P-L., Noterdaeme, O. and Naik, K. 2016. Digital in Industry: From Buzzword to Value Creation. New York, McKinsey \& Company. Available at https://www.mckinsey.com/business-functions/ mckinsey-digital/our-insights/digital-in-industryfrom-buzzword-to-value-creation

Demeter, K., Losonczi, D., Nagy, J. and Horváth, B. 2019. Tapasztalatok az ipar 4.0-val - Egy esetalapú elemzés (Industry 4.0 experiences - A case-based analysis). Vezetéstudomány 50. (4): 11-23. Doi: 10.14267/VEZTUD.2019.04.02

DESI 2019. A digitális gazdaság és társadalom fejlettségét mérő mutató, országjelentés (Indicator of the development of the digital economy and society, country report.) European Commission. Available at https://ec.europa.eu/hungary/news/2019061__ desi2019_hu

Devezas, T., Leităo, J. and Sarygulov, A. (eds.) 2017. Industry 4.0. Entrepreneurship and Structural Change in the New Digital Landscape. Heidelberg, Springer International Publishing AG. Doi: 10.1007/978-3319-49604-7

DIHK 2015. Wirtschaft 4.0: Große Chancen, viel zu tun. Dresden, IHK. Available at https://invest.dresden. de/csdata/download/1/de/wirtschaft_4_0_ihk_unternehmensbarometer_zur_digitalisierung_434.pdf

EISERT, R. 2014. Sind Mittelständler auf Industrie 4.0 vorbereitet? WirtschaftsWoche, 21. Oktober 2014. Available at https://www.wiwo.de/unternehmen/mittelstand/innovation-readiness-indexsind-mittelstaendler-auf-industrie-4-0-vorbereitet/10853686.html

ERdeI, E. 2019. Az Ipar 4.0 fejlődése, használata és kihívásai napjainkban (Recent development, use and challenges of Industry 4.0). Acta Carolus Robertus 9. (1): 49-63. Doi:10.33032/acr.2019.9.1.49

FonseCA, L.M. 2018. Industry 4.0 and the digital society: concepts, dimensions and envisioned benefits. Proceedings of the $12^{\text {th }}$ International Conference on Business Excellence. Sciendo 12. (1): 386-397. Doi: 10.2478/pichbe-2018-0034.

Geissbauer, R., Vedso, J. and Schrauf, S. 2016. Industry 4.0: building the digital enterprise. Global Industry
4.0. Survey. London, PricewaterhouseCoopers. Available at https://www.pwc.com/gx/en/industries/industries-4.0/landing-page/industry-4.0building-your-digital-enterprise-april-2016.pdf

Grasland, L. and Puel, G. 2007. The diffusion of ICT and the notion of the digital divide: contribution from franchophone geographers - Introductory remarks. GeoJournal 68. (1): 1-3.

Hermann, M., Pentek, T. and Отto, B. 2015. Design Principles for Industrie 4.0 Scenarios: A Literature Review. Working Paper. 1. Dortmund, Technische Universität. Available at https://www.researchgate. net/publication/307864150_Design_Principles_for_ Industrie_40_Scenarios_A_Literature_Review

Holodny, E. 2017. A key player in China and the EU'S "third industrial revolution" describes the economy of tomorrow. New York, Business Insider Inc. Available at https://www.businessinsider.com.au/jeremyrifkin-interview-2017-6

Horváth, D. and Szabó, R.Zs. 2019. Driving forces and barriers of Industry 4.0: Do multinational and small and medium-sized companies have equal opportunities? Technological Forecasting \& Social Change 146. (September): 119-132. Doi: 10.1016/j. techfore.2019.05.021

Houzet, S. 2007. The diffusion of ICT in France: infrastructures, services, and uses. GeoJournal 68. (1): 5-17. Doi: 10.1007/s10708-007-9049-0

Ibarra, D., Ganzarain, J. and Igartua, J.I. 2018. Business model innovation through Industry 4.0: A review. Procedia Manufacturing 22. (1): 4-10. Available at https://www.sciencedirect.com/journal/procedia-manufacturing/vol/22/

Kopp, J. and BAsL, J. 2017. Study of the readiness of Czech companies to the Industry 4.0. Journal of Systems Integration 4. (3): 40-45.

KovÁcs, O. 2017. Az Ipar 4.0 komplexitása - I. (The complexity of Industry 4.0 - I). Közgazdasági Szemle 64. (7-8): 823-851. Doi: 10.18414/KSZ.2017.7-8.823

Lengyel, I. and VARGA, A. 2018. A magyar gazdasági növekedés térbeli korlátai - helyzetkép és alapvető dilemmák (Spatial constraints of Hungarian economic growth - state of affairs and fundamental dilemmas). Közgazdasági Szemle 65. (5): 499-524. Doi: 10.18414/KSZ.2018.5.499

Luthra, S. and MANGLA, S.K. 2018. Evaluating challenges to Industry 4.0 initiatives for supply chain sustainability in emerging economies. Process Safety and Environmental Protection 117. (July): 168-179. Doi: 10.1016/j.psep.2018.04.018

MокуR, J. 1985. The New Economic History and the Industrial Revolution. Washington D. C., Rowman and Littlefield Publishers.

Müller, J.M., Buliga, O. and Voigt, K-I. 2018. Fortune favors the prepared: How SMEs approach business model innovations in Industry 4.0. Technological Forecasting \& Social Change 132. (C): 2-17. Doi: 10.1016/j.techfore.2017.12.019 
Nagy, Cs. and Molnár, E. 2018. Az Ipar 4.0 területi összefüggései a robotizáció tükrében: milyen hatásai lehetnek a folyamatnak Magyarországon? (Spatial connections of Industry 4.0 in the mirror of robotization: what kind of impacts of this process can have on Hungary?) Területfejlesztés és Innováció 12. (2): 3-18. Available at http://real.mtak.hu/id/eprint/100050

Nagy, Cs., Molnár, E. and Kiss, É. 2020. Industry 4.0 in a dualistic manufacturing sector- qualitative experiences from enterprises and their environment, Eastern Hungary. Hungarian Geographical Bulletin 69. (2): 157-174.

NAGY, J. 2019. Az Ipar 4.0 fogalma és kritikus kérdései - vállalati interjúk alapján (The concept and critical issues of Industry 4.0 by company interviews). Vezetéstudomány 50. (1): 14-27. Doi: 10.14267/ VEZ TUD.2019.01.02

Nedelka, E. 2019. Magyarország infokommunikációs fejlődésének és fejlettségének vizsgála 2010 és 2017 között (The examination of infocommunication development in Hungary between 2010 and 2017). Manuscript. Sopron, Soproni Egyetem LKK.

Nemes Nagy, J. and Lőcsei, H. 2015. Hosszú távú megyei ipari növekedési pályák (1964-2013). (Long term industrial development trends by county [1964-2013]). Területi Statisztika 55. (2): 100-121.

Nick, G. 2018. Az Ipar 4.0 hazai adaptációjának kihívásai a vállalati és területi összefüggések tükrében (The challenges of adaptation of industry 4.0 in Hungary in corporate and territorial context). PhD Thesis. Győr, Széchenyi István Egyetem, Regionális- és Gazdaságtudományi Doktori Iskola.

Nick, G., VÁrgedô, T., NAgy, Cs. and Szaller, Á. 2019. The territorial contexts of Industry 4.0 in Hungary, the present and future challenges and expectations of the digital ecosystem. DETUROPE - The Central European Journal of Regional Development and Tourism 11. (3): 29-57.

Rechnitzer, J., Grosz, A. and Csizmadia, Z. 2003. A magyar városhálózat tagozódása az infokommunikációs infrastruktúra alapján az ezredfordulón (The Hungarian urban networks' structure based on the information and communication infrastructure at the turn of the Millennium). Tér és Társadalom 17. (3): 145-197. Available at https://tet. rkk.hu/index.php/TeT/article/download/905/1807/

Reischauer, G. 2017. Industry 4.0 as policy-driven discourse to institutionalize innovation systems in manufacturing. Technological Forecasting and Social Change 132. (C): 26-33. Doi: 10.1016/j.techfore.2018.02.012

Rosina, K. and Hurbánek, P. 2013. Internet availability as an indicator of peripheriality in Slovakia. Moravian Geographical Reports 21. (1): 16-24. Available at https:/www.geonika.cz/EN/research/ ENMGRClanky/2013_1_ROSINA.pdf

Rüssmann, M., Lorenz, M., Gerbert, P., Waldner, M., Justus, J., Engel, P. and Harnisch, M. 2015.
Industry 4.0. The future of productivity and growth in manufacturing industries. Boston, MA, The Boston Consulting Group. Available at https://www.bcg. com/publications/2015/engineered_products_project_business_industry_4_future_productivity_ growth_manufacturing_industries.aspx

Santos, C., Mehrsai, A., Barros, A.C., Araujo, M. and Ares, E. 2017. Towards Industry 4.0: an overview of European strategic roadmaps. Procedia Manufacturing 13. 972-979. Doi: 10.1016/j.promfg.2017.09.093

Scнmidt, H. 2014. Der Hype um Industrie 4.0 ist vorbei: Verspielt Deutschland seine Zukunft? t3n digital pioneers - Das Magazin für digitales Business. Available at https://t3n.de/news/industrie4-0-deutschland-585460/

Šlander, S. and Wostner, P. 2019. Transformation and transition to Industry 4.0: the Slovenian smart transformational approach. In Revitalising Lagging Regions: Smart Specialization and Industry 4.0. Regional Studies Policy Impact Books 1. (2). Eds.: Barzotto, M., Corradini, C., Fai, F.M., Labory, S. and Tombinson, P.R., Brighton, UK, RSA, 55-66. Doi: 10.1080/2578711X.2019.1621101

Sсншав, K. 2016. The Fourth Industrial Revolution. Cologne-Geneva, World Economic Forum, Available at https://www.weforum.org/about/the-fourthindustrial-revolution-by-klaus-schwab

Sommer, L. 2015. Industrial revolution - Industry 4.0: Are German manufacturing SMEs the first victims of this revolution? Journal of Industrial Engineering and Management 8. (5): 1512-1532.

Thoben, K.D., Wiesner, S.A. and Wuest, T. 2017. "Industrie 4.0" and smart manufacturing - a review of research issues and application examples. International Journal of Automation Technology 11. (1): 4-16. Doi: 10.20965/ijat.2017.p0004

Tranos, E. and NiJKamP, P. 2013. A távolság halálának új vizsgálata: kiberhely, földrajzi és kapcsolati közelség (The death of distance revisited: cyberplace, physical and relational proximities). Tér és Társadalom 27. (3): 3-27. Doi: 10.17649/TET.27.3.2561

Winter, J. 2020. The evolution and disruptive potential of Industrie 4.0. Hungarian Geographical Bulletin 69. (2): 83-97.

Zezulka, F., Marcon, P., Vesely, I. and Sajdl, O. 2016. Industry 4.0 - An introduction in the phenomena. IFAC-PapersOnLine 49. (25): 8-12. Doi: 10.1016/j. ifacol.2016.12.002 
